\title{
Meer dan eenden voederen
}

\author{
Nieuwe literatuur over keizer Wilhelm II en Nederland \\ Martin Kohlrausch \\ TVGESCH 130 (4): 625-642 \\ DOI: 10.5117/TVGESCH2017.4.KOHL
}

\begin{abstract}
More than feeding the ducks. New literature on Emperor Wilhelm II and The Netherlands This article reviews a number of recent publications on Kaiser Wilhelm II in the Netherlands in order to reflect on the place of Wilhelm II in this country's history. With the flight of Wilhelm II to the Netherlands on 10 November 1918 an 'involuntary relationship' began, which necessarily reflected the Dutch perception of the Great War but also of Germany itself. Huis Doorn, the residence Wilhelm II used for the greater part of the twenty-three years he spent in the Netherlands, thus turned into an unlikely place of memory, the meaning of which has recently been renegotiated.
\end{abstract}

Keywords: Wilhelm II, Huis Doorn, World War One, German Monarchy, Politics of Memory

In 1999 boekte de Duits-Nederlandse filmdocumentaire 'Majestät brauchen Sonne' van Peter Schamoni een verrassend succes aan de Duitse bioscoopkassa's. Schamoni confronteerde het Duitse publiek met de laatste Duitse keizer Wilhelm II, een figuur die de meeste Duitsers in het gunstigste geval nog in anekdotische vorm kenden. ${ }^{1}$ In de talrijke voordien vergeten filmstukjes trad de keizer enerzijds op als merkwaardig anachronisme, omgeven

1 'Majestät brauchen Sonne', in: Hilmar Hoffmann ed., Peter Schamoni. Filmstücke/Film Pieces (Stuttgart 2003) 62-83. Ik dank Elly Collin en Betto van Waarden voor ondersteuning bij het afwerken van deze tekst. door allerhande Pruisische militairen, paarden en andere kenmerken van een lang vervlogen tijd. Anderzijds kwam Wilhelm II verrassend hedendaags over, waaraan vooral de bewegende beelden, enkele zelfs in kleur, bijdroegen. Het einde van de film verplaatst de aandacht naar het museum Huis Doorn waar een gids aan een aantal bezoekers een kies van Wilhelm II toont, verbonden met de vrij ontstellende boodschap dat de tand het, in theorie, mogelijk zou maken om Wilhelm II te klonen.

De meeste mensen, ook in Duitsland, zullen er blij om zijn dat het nog wat 
wachten is op deze technische vooruitgang. Desondanks is er al ongeveer 20 jaar sprake van een hernieuwde belangstelling voor de figuur van de keizer. $\mathrm{Na}$ de Tweede Wereldoorlog waren conservatieve Duitse historici er nauwelijks in geinteresseerd om over deze redelijk pijnlijke calamiteit te spreken en progressieve historici zagen dan weer weinig nut in het genre van de biografie en de focus op een specifiek persoon. Vanaf de jaren negentig echter begon Wilhelm II een nieuw leven in de (cultuur)geschiedschrijving waartoe indirect ook Schamoni's documentaire heeft bijgedragen. Net als in deze film gaat het in de meerderheid van de in de laatste twee decennia verschenen boeken er niet zozeer om de historische schuld van de keizer te vatten, maar bestuderen zij het fenomeen Wilhelm II op zich. Deze studies, vaak door niet-Duitse historici geschreven, bedden Wilhelm II in bredere maatschappelijke en culturele ontwikkelingen in. De auteurs gebruiken Wilhelm II als een casus om de Duitse en Europese maatschappijen rond 1900 beter te begrijpen. Technologische vooruitgang, de opkomst van de massamedia of algemene tendensen van democratisering hadden immers ook een grote impact op de monarchie en de figuur van de monarch. ${ }^{2}$ Dit betekende uiteraard niet dat het negatieve oordeel over de keizer direct wijzigde, maar had wel tot gevolg dat vele

2 Voor een overzicht van de recente literatuur over Wilhelm II zie: Martin Kohlrausch, 'Zu Wilhelm II. noch etwas Neues? Tendenzen der Forschung der letzten zwei Jahrzehnte', in: Johannes Franzen, Nicolas Detering, Christopher Meid ed., Herrschaftserzählungen. Wilhelm II in der Kulturgeschichte (1888-1933) (Würzburg 2016) 19-37. Voor het verband tussen massamedia en monarchie zie: Martin Kohlrausch, Der Monarch im Skandal. Die Logik der Massenmedien und die Transformation der wilhelminischen Monarchie (Berlijn 2005). onderzoekers, bijna honderd jaar na de val van het Duitse keizerrijk, nuchterder naar zijn belangrijkste representant begonnen te kijken.

In zekere mate speelt deze trend, zoals enkele recente publicaties tonen, ook in Nederland. Weliswaar bleef en blijft de relatie van Nederland en Wilhelm II van heel specifieke aard sinds de ex-keizer aan het einde van de Eerste Wereldoorlog voor beide kanten onvrijwillig deel werd van de Nederlandse geschiedenis.

Bijzonder enthousiast was in Nederland niemand toen Wilhelm II op 10 november 1918 in Eijsden het Nederlands grondgebied betrad. Koningin Wilhelmina en zeker ook het Nederlandse kabinet vreesden vrij terecht dat de socialistische beweging de komst van de keizer als een provocatie zou zien. Nederland bood immers gastvrijheid aan iemand die in heel Europa, behalve in Duitsland, de reputatie van voornaamste verantwoordelijke voor de oorlog en talloze oorlogsmisdaden had verworven. De Nederlandse regering was er veel aan gelegen om de commotie over de gast te beperken en low key te spelen. Omwille van talrijke duidelijk dringender problemen verdween Wilhelm II min of meer van het Nederlandse en internationale toneel. Slechts enkele keren, in 1919 en 1920, kwam hij weer in beeld toen de Nederlandse regering met de vraag van de voormalige Entente-mogendheden werd geconfronteerd om Wilhelm II, zoals voorzien in het verdrag van Versailles, uit te leveren en voor een internationaal tribunaal te brengen. De eerste tijd bracht Wilhelm II en een klein maar nog altijd aanzienlijk deel van zijn entourage door als gast van de Graaf Godard van Bentinck in Amerongen. Na anderhalf jaar, veel langer dan verwacht, kon hij zich in 1920 in het 
Huis Doorn in de buurt van Utrecht vestigen, waar hij tot zijn dood in juni 1941 een in verschillende opzichten bizar miniatuurhof zou voorzitten. Een politieke rol in de engere zin speelde de keizer nu niet meer. $^{3}$

Er zijn dus goede redenen waarom Wilhelm II's 23-jarige ballingschap in Nederland lang weinig aandacht heeft gevonden. ${ }^{4}$ Het feit dat de voormalige keizer er geen been in zag Hitler na de Duitse invasie van Frankrijk te feliciteren (en dus indirect liet blijken voor de overwinning van Duitse troepen in Nederland te zijn) heeft er niet toe bijgedragen de sowieso nooit bijzonder grote sympathie voor de Duitse monarch in Nederland te versterken. Desalniettemin bleef, hoewel op een meer lokaal vlak, de keizer in zekere zin in Nederland aanwezig door zijn materieel erfdeel in Doorn dat door de naoorlogse onteigening ook in juridische zin deel van Nederland werd.

Enkele recent in Nederland verschenen werken met elk een heel verschillende opzet werpen nieuw licht op de verhouding tussen Wilhelm II en Nederland en de daarachter liggende problemen. Naar aanleiding van de tentoonstelling 'Der Kaiser! Glorie \& ondergang van keizer Wilhelm II' die tot en met februari 2016 te zien was in Paleis het Loo heeft Jan J.B. Kuipers een rijk geïllustreerde band gepubliceerd. Dit boek is in de eerste plaats bedoeld voor een groot publiek, maar omdat het aansluit bij een bredere stroming in de benadering van Wilhelm II blijkt het ook voor

3 Sally Marks, "My name is Ozymandias": The Kaiser in exile', Central European History 16.2 (1983) 122170.

4 Een van de weinige uitzonderingen: J.A. de Jonge, Wilhelm II. Keizer van Duitsland (Amsterdam 1986). vakhistorici interessant. ${ }^{5}$ Van een heel andere aard is het onder meer door enkele professionele juristen geschreven boek Het proces tegen Wilhelm II. Een vonnis over de schuld van de Duitse keizer aan WO I. De auteurs Hans Andriessen, Paul Mevis en Willem Sinninghe Damsté laten hierin het proces tegen Wilhelm II plaatsvinden dat kort na de oorlog gepland was maar nooit tot stand kwam en zij vellen een vrij mild oordeel - uiteraard volledig symbolisch en daarmee een eigenaardig voorbeeld van counter factual geschiedschrijving. ${ }^{6}$ Vanuit een historisch perspectief is de interessantste verschijning onder de recente publicaties een van een uitvoerige inleiding voorziene nieuwe uitgave van de dagboeken van Sigurd von Ilsemann, vleugeladjudant van Wilhelm II sinds de laatste maanden van de Grote Oorlog tot het overlijden van Wilhelm II in 1941 in Doorn. ${ }^{7}$ Het is deze publicatie waarop de volgende overwegingen vooral zullen ingaan.

De drie publicaties tonen aan dat hoewel de politieke functie van Wilhelm II in november 1918 eindigde hij een belangrijke rol bleef spelen - niet op zijn minst voor het beeld van Duitsland in Nederland. Deze publicaties, en het eigenaardige verhaal van de 23 jaar die Wilhelm II in Nederland doorbracht, dienen als aanleiding om de plaats van Wilhelm II in de hedendaagse, vooral Nederlandse, geschiedschrijving maar ook in de bredere maatschappelijke discussie omtrent de

5 Jan J.B. Kuipers, Der Kaiser! Glorie \& ondergang van keizer Wilhelm II (Zutphen 2015).

6 Hans Andriessen, Paul Mevis en Willem Sinninghe Damsté, Het proces tegen Wilhelm II. Een vonnis over de schuld van de Duitse keizer aan WO I (Houten 2016). 7 Sigurd von Ilsemann, Wilhelm II in Nederland 19181941. Dagboekfragmenten bezorgd door Jacco Pekelder en Wendy Landewé (Soesterberg 2015). 


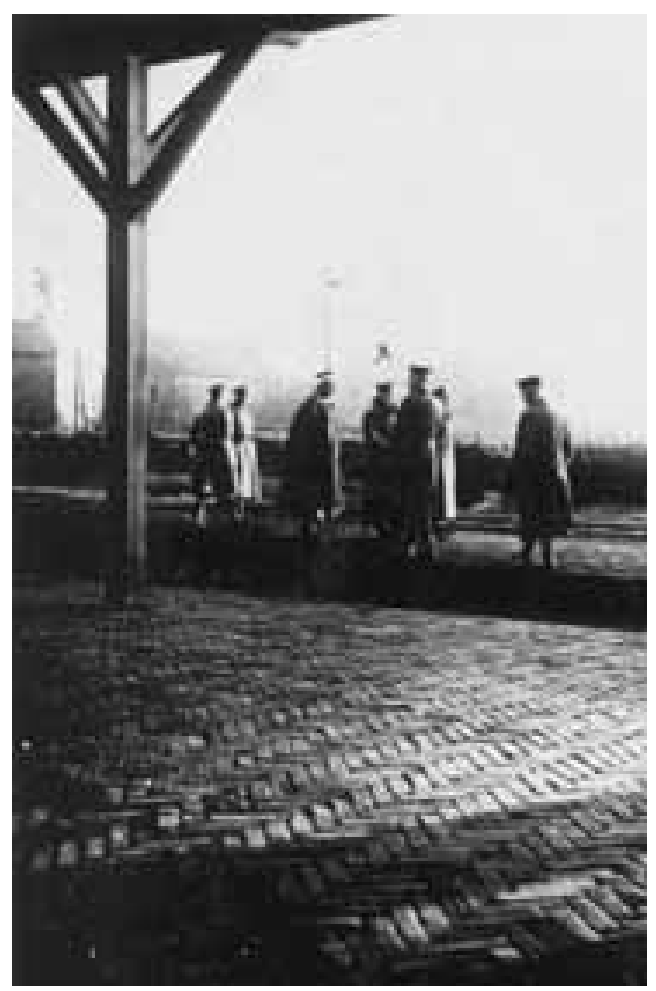

Op 10 november 1918 geraakte Wilhelm II onder avontuurlijke omstandigheden naar de Nederlandse grensstad Eijsden. Op het perron van het station van Eijsden wachtten de exkeizer (met pels) en zijn entourage tot de Nederlandse regering toestemming gaf hem het land binnen te laten.

Collectie Museum Huis Doorn

laatste Duitse keizer te schetsen. ${ }^{8}$ Daarbij zal dit artikel een breed gamma van literatuur behandelen: naast enkele nieuwere wetenschappelijke monografieën, artikels en bronnenedities worden ook tentoonstellingscatalogi en ten slotte populair we-

8 Een hernieuwde interesse in Wilhelm II wordt ook getoond door enkele populariserende publicaties. Zie bijv. het themanummer 'Huis Doorn en de Eerste Wereldoorlog', ThemaTijdschrift 4.2 (2014). Een bijzonder sprekend voorbeeld van popularisering is het historisch redelijk verantwoorde stripboek: Hennie Vaesen, De Keizer die zijn land ontvluchtte: een historisch beeldverhaal (Oosterbeek 2016). tenschappelijk literatuur besproken. Het artikel zal eerst op Ilsemann en zijn dagboeken ingaan, dan de politieke belangstelling van Ilsemanns optekeningen in het licht van nieuwere publicaties analyseren en ten slotte, uitgaand van Huis Doorn als plaats van de ballingschap van Wilhelm II en museum in het hedendaagse Nederlandse geschiedenislandschap, enkele bedenkingen over de plaats van Wilhelm II in de herinneringspolitiek in Nederland en Duitsland formuleren.

\section{Sigurd von Ilsemann: zijn dagboeken en de ex-keizer}

Sigurd von Ilsemann (1884-1952) was in vele opzichten bepaald geen eersterangs historische figuur. ${ }^{9}$ Hij had geen beslissende functie en ook als kroniekschrijver is hij niet door een neutrale positie bijzonder gekwalificeerd. Had hij niet de 'Pruisische waarden', het monarchisme en de uitgelichte rol van het militaire gedeeld, dan zou hij nooit in deze positie geraakt zijn. Maar Ilsemann, afkomstig uit het Noord-Duitse Lüneburg, was ook niet de karikatuur van de 'ostelbische' Pruisische Junker. Veeleer werd hij in de zomer van 1918 als vleugeladjudant gekozen omdat hij zelfstandig oordeelde en het Duitse hoofdkwartier van mening was dat hij tussen de meer en meer eigenaardige en afgesloten wereld van Wilhelm II en de altijd grijzere realiteit buiten het hoofdkwartier zou kunnen bemiddelen.

Wat Ilsemann voor historici belangrijk maakt, is zijn positie van nabijheid op een moment dat de ontwikkeling van de Duitse monarchie in een stroomversnelling terechtkwam. Tevens maakt hij diezelfde

9 Kuipers, Kaiser, 90-91. 
monarchie, maar dan in een gekrompen versie, nog 23 jaar lang mee in Nederland. Ilsemanns nauwkeurige, heldere en vrij reflecterende herinneringen voegen dus enerzijds waardevolle perspectieven toe aan een aantal andere stemmen uit het Duitse hoofdkwartier in Spa. ${ }^{10}$ Door Ilsemann krijgen we een beter zicht op wat er de laatste dagen in Spa gebeurde en welke motieven er speelden in de beslissing om de keizer naar Nederland te sturen (blijkbaar was de keizer niet meer in staat zelf het initiatief te nemen). Ilsemann levert nauwkeurige beschrijvingen van de vlucht naar Nederland, de situatie aan de grens in Eijsden en de overstap naar Amerongen. De beschrijvingen bieden naast de door Friedrich Rosen, de Duitse ambassadeur in Den Haag, geschreven herinneringen, de meest gedetailleerde benadering van deze ook voor Nederland belangrijke gebeurtenissen.

Anderzijds zijn de herinneringen vanuit een Nederlandse perspectief vooral significant voor de jaren in Doorn. Voor deze tijd is Ilsemanns verslag inderdaad een 'sleuteltekst'. ${ }^{11}$ Weliswaar zijn er andere beschrijvingen over de 23 jaar die Wilhelm II in Nederland doorbracht - in-

10 Zie bijv. Holger Afflerbach ed., Kaiser Wilhelm II. als Oberster Kriegsherr im Ersten Weltkrieg. Quellen aus der militärischen Umgebung des Kaisers. 1914-1918 (München 2005); Frank Betker en Almut Kriele ed., Pro Fide et Patria. Die Kriegstagebücher von Ludwig Berg 1914 bis 1918. Katholischer Feldgeistlicher im Großen Hauptquartier Kaiser Wilhelms II. (Keulen 1998).

11 Jacco Pekelder, 'Leven in een luchtkasteel. De dagboeken van Sigurd von Ilsemann als historisch document over Wilhelm II', in: Ilsemann, Wilhelm II in Nederland, XII. clusief bronnen uit een oral history-project. ${ }^{12}$ Maar omwille van de nauwkeurig bijgehouden informatie over een lang tijdperk en de intieme informatie die Ilsemann op basis van zijn positie kon verkrijgen en ook dankzij Ilsemanns vaardigheden als redelijk kritische waarnemer gaat het hier om een uniek document. De lectuur is niet altijd even plezierig omdat Ilsemann zonder filter de vaak vervelende dagelijkse routines in Huis Doorn weergeeft. Maar Ilsemann levert wel een soort onvrijwillige cultuurgeschiedenis van een historische en psychologische extreemsituatie. Hoe kritisch Ilsemann ook tegenover de keizer stond en ondanks de jaren van desillusie, laat zijn opvatting van trouw het blijkbaar niet toe Doorn te verlaten. Ilsemann is bereid voor de ex-keizer zowel zijn militaire loopbaan in Duitsland alsook een groot deel van zijn familieleven op te offeren: hij trouwt al in 1920 met Gravin Elisabeth van Bentinck, de dochter van Wilhelm II's gastheer in Amerongen. Net als tijdens de laatste dagen in Spa slaagt Ilsemann er in Doorn in om Wilhelm II zo goed mogelijk te confronteren met de realiteit buiten dat vrij afgesloten eiland en tegelijkertijd onverantwoorde uitspraken en handelingen van de ex-keizer te voorkomen.

Wie is de ex-keizer die in de dagboeken van Ilsemann optreedt? Wilhelm II komt alles behalve sympathiek over en de meest positieve commentaren van Ilsemann hebben er meestal mee te maken

12 Zie Wendy Landewé, 'Mit dem Kaiser ins Exil. Die Tagebücher von Sigurd von Ilsemann (1884-1952)', in: Gunnar Teske ed., Adelige über sich selbst. Selbstzeugnisse in nordwestdeutschen und niederländischen Adelsarchiven (Münster 2015) 89-100, aldaar 98. Een populariserende benadering is: Perry Pierik en Henk Pors, De verlaten Monarch. Keizer Wilhelm II in Nederland (Soesterberg 1999). 
dat de keizer zijn lot enigszins weet te aanvaarden. Naast enkele min of meer zwaarwegende karaktergebreken vertoont Wilhelm II ook nog altijd vele van de kenmerken die hem al voor 1914 zowel in Duitsland als daarbuiten tot een - voorzichtig geformuleerd - controversiële figuur hadden gemaakt. Hij is zelfingenomen, niet bereid fouten toe te geven, gevangen in Duits-nationalistische en zelfs simpelweg antisemitische verklaringen met zichzelf als vermeend slachtoffer van allerhande samenzweringen.

Nauwelijks verrassend is het dus dat zelfs op het hoogtepunt van de crisis van de Weimarrepubliek een restauratie van de monarchie met Wilhelm II als keizer nooit realistisch bleek. Maar al die gebreken, vooral het in het oog springende gebrek aan consistente overwegingen en aan mensenkennis dat de keizer vaak parten speelt, werpen ook de vraag op hoe het oorlogsbeeld van Wilhelm II beantwoordt aan de realiteit. Zelfs John Röhl, de voornaamste biograaf van Wilhelm II, kan moeilijk verklaren hoe iemand die er moeite mee had om een zaak over een langer tijdperk te volgen en door te drijven planmatig een heel continent in het verderf kon storten. ${ }^{13}$ Deze spanning geldt ook voor de restauratieplannen die bij Willibald Gutsche, die de belangrijkste studie over de ballingschapsjaren van Wilhelm II heeft geschreven, toch wat consistenter overkomen dan uit de dagboeken van Ilsemann blijkt. ${ }^{14}$ Uiteraard betekent dit niet dat Wilhelm daarom als politicus

13 John C.G. Röhl, Wilhelm II. Der Aufbau der Persönlichen Monarchie, 1888-190o (München 2001) en Wilhelm II. Der Weg in den Abgrund, 1900-1941 (München 2008).

14 Willibald Gutsche, Ein Kaiser im Exil. Der letzte deutsche Kaiser Wilhelm II. in Holland (Marburg 1991) 83-110. positiever te beoordelen is, maar eerder dat we de impact van het politieke handelen van Wilhelm II niet moeten overdrijven.

De ontstaansgeschiedenis van de dagboeken van Ilsemann is op zich al een complex verhaal. Hoewel zijn dagelijkse functies Ilsemann nauwelijks tijd voor een privéleven lieten, heeft hij op een regelmatige basis zijn dagboek aangevuld. Zich blijkbaar bewust van de unieke waarde van zijn getuigenis, heeft Ilsemann de boeken kort voor de Duitse invasie van Nederland in Huis Doorn ingemetseld. ${ }^{15}$ Pas in 1967 , vijftien jaar na de dood van Ilsemann en lang na de grote debatten over de monarchie in het interbellum die door de verschillende toen gepubliceerde memoires van leden van de wilhelminische elite werden aangewakkerd, werden de dagboeken door de Duitse schrijver Harald von Königswald uitgegeven. ${ }^{16}$ Königswald heeft echter delen van Ilsemanns dagboeken niet in de uiteindelijke editie opgenomen. Het is bovendien mogelijk dat Königswald, conservatief gezind maar geen nazi, bepaalde passages door weglatingen of zelfs veranderingen heeft gewijzigd, zeker als het om kritische thema's zoals de vlucht van Wilhelm II of diens houding tegenover de nazi's gaat.

Kort na de Duitse uitgave, die toen enige belangstelling in de Duitse en internationale media verkreeg, verscheen er

15 Landewé, Mit dem Kaiser ins Exil, 98.

16 Sigurd von Ilsemann, Der Kaiser in Holland. Aufzeichnungen des letzten Flügeladjutanten Kaiser Wilhelms II. Amerongen en Doorn 1918-1923, en II, Monarchie und Nationalsozialismus, 1924-1941, red. Harald von Königswald (München 1967-1968). 


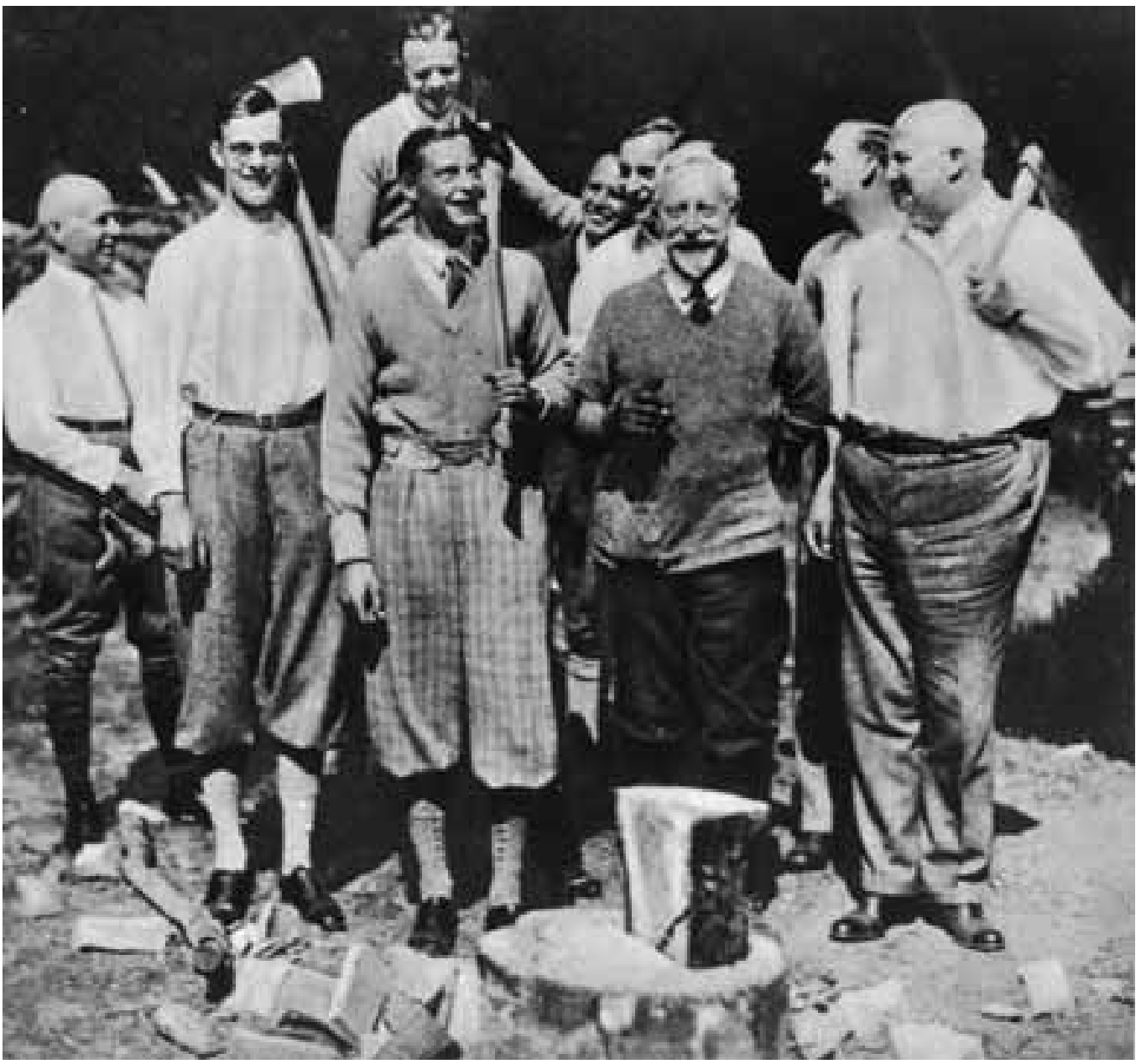

Wilhelm II met familieleden en Ilsemann na het beroemd-beruchte houthakken in het park van Doorn. Collectie Nationaal Archief, Anefo / fotograaf onbekend

een Nederlandse vertaling. ${ }^{17}$ Hoewel deze editie vandaag de dag nog maar moeilijk te verkrijgen is, zou men de vraag kunnen stellen of een nieuwe uitgave nodig was. De bezorgers van de in 2015 verschenen vertaling - Jacco Pekelder en Wendy Landewé - geven twee redenen voor de beslissing om met medewerking van een aantal gevorderde studenten van de Uni-

17 Sigurd von Ilsemann, Der Kaiser in Nederland, I, Aantekeningen van de laatste vleugeladjudant van keizer Wilhelm II uit Amerongen en Doorn 1918-1923 en II, Monarchie en nationaal-socialisme. Aantekeningen uit de jaren 1924-1941 (Baarn 1968-1969). versiteit Utrecht de dagboeken opnieuw te publiceren. De dagboeken werden opnieuw vertaald in een poging het karakter van Ilsemanns notities beter weer te geven en voor een hedendaags publiek vatbaarder te maken. Bovendien vullen beknopte noten de dagboeken aan en maken deze het voor de hedendaagse lezer gemakkelijker de tekst, vooral verwijzingen naar personen en plaatsen, te begrijpen. Daarenboven hebben de uitgevers een persoonsregister toegevoegd. Een nieuwe invalshoek bieden ook enkele tot nu toe onbekende foto's die vaak heel 
goed met de tekst corresponderen. Een grote troef is vooral de kennisrijke, door Pekelder, verzorgde inleiding waarin hij ook op de grenzen van de nieuwe uitgave ingaat. Deze grenzen worden nog altijd mede bepaald door Ilsemanns familie, waarvan enkele leden blijkbaar aan de uitgave meewerkten, maar die niet bereid was het oorspronkelijke typoscript van Ilsemann aan de bezorgers ter beschikking te stellen. De niet helemaal onbelangrijke vraag in hoeverre kritische passages zijn verwijderd of veranderd, blijft dus onbeantwoord.

Niettemin is het de moeite om hier op enkele algemenere thema's in Ilsemanns dagboeken nader in te gaan. Het zou zeker te kort schieten het miniatuurhof in Doorn enkel als een soort epiloog van de 30-jarige regering van Wilhelm II te interpreteren. Wat de grote politieke lijnen betreft, zijn drie vraagstukken belangrijk: ten eerste, de troonsafstand en vlucht, ten tweede, het uitleveringsvraagstuk en de rol van de keizer in de internationale politiek na 1918, en ten derde, de houding van Wilhelm II tegenover het nationaalsocialisme. Uiteraard zou Wilhelm II niet meer doorslaggevend in de Duitse of Nederlandse politiek ingrijpen. Maar in Huis Doorn kwamen wel thema's aan bod die vóór 1918 geen of een veel beperktere rol hadden gespeeld. In ballingschap ageert Wilhelm II niet meer op het eerste plaats als drager van een ambt. Hierdoor verandert bijvoorbeeld zijn houding tegenover zijn eigen familie en persoonlijke interesses en bekommerdheden worden duidelijker zichtbaar dan voor 1918. Daarnaast werpen vele van de politiek-maatschappelijke ideeën van de Doornse Exil-monarch - vooral zijn antisemitisme - een zeker licht op de periode voor en tijdens de Eerste Wereldoorlog. En ten slotte was het ook belangrijk wat Wilhelm II juist niet deed, bijvoorbeeld het nationaalsocialisme openbaar steunen of verdoemen, of echt werk maken van de vele monarchistische plannen voor een restauratie.

\section{De politieke betekenis van Ilsemanns optekeningen}

Het is al lang bekend hoe de laatste dagen zich in het keizerlijke hoofdkwartier in Spa afspeelden. De nog altijd ter discussie staande vraag of een vroegere troonsafstand de dynastie had kunnen redden, moet sowieso in een breder kader worden bekeken dan de dagboeken van Ilsemann toelaten. ${ }^{18}$ Wat in Ilsemanns geschriften gedetailleerd naar voren komt, is een sfeer waarin niemand het waagt om beslissingen te nemen en die vervolgens op 9 en 10 november 1918 tot een chaotische en totaal geïmproviseerde situatie leidt. Het lijkt aannemelijk dat men - wie precies is moeilijk te vatten - wel voorbereidingen voor een Nederlands asiel voor Wilhelm II had getroffen. ${ }^{19}$ Waarschijnlijk werden er al enkele dagen voor de vlucht van Wilhelm II in het Duitse hoofdkwartier algemene afspraken met de Nederlandse regering gemaakt, waarbij koningin Wilhelmina zich blijkbaar had laten leiden door een soort dynastieke solidariteit, eventueel ook resten van oude

18 Wolfram Pyta, 'Die Kunst des rechtzeitigen Thronverzichts. Neue Einsichten zur Überlebenschance der parlamentarischen Monarchie in Deutschland im Herbst 1918', in: Patrick Merziger e.a. ed., Geschichte, Öffentlichkeit, Kommunikation. Festschrift für Bernd Sösemann zum 65. Geburtstag (Stuttgart 2010) 363-381. 19 Voor de houding van Nederland zie: Rolf ter Sluis, De 'Keizer-quaestie': Nederland en de vlucht van Wilhelm II, november 1918-maart 1920 (Doorn 1996). 
Oranje-Hohenzollernverbondenheid en het negatieve voorbeeld van het lot van de tsaristische familie een jaar eerder in Rusland. ${ }^{20}$ De verklaring dat de Nederlandse generaal Joannes Benedictus van Heutsz, de voormalige gouverneur van Nederlands-Indië, uit puur militaire interesse van 5 tot 9 november in Spa verkeerde, was in ieder geval alles behalve geloofwaardig. Evenzo valt het op dat enkele het keizerrijk gezinde militairen en politici in Nederland hun deel bijdroegen om een op zich enorm ingewikkelde operatie - die men pas later als typisch Nederlandse gastvrijheid ging verklaren - te laten slagen. ${ }^{21}$

Ondanks de naar alle waarschijnlijkheid getroffen voorzorgen verliep de tocht van Spa naar het grensstation Eijsden zeker niet ontspannen voor de keizer. ${ }^{22}$ In de gedenkwaardige woorden van Wilhelm II kort voor zijn vertrek in Spa, dat hij niet naar Nederland zou gaan omdat daar misschien ook een revolutie zou uitbreken en het antwoord van een lid van de entourage dat dit niet waarschijnlijk was en zelfs al mocht dit gebeuren, dan nog zou zo een revolutie zeker veel milder verlopen, komt tot uitdrukking hoe binnen enkele uren een hele wereld ineenstortte. ${ }^{23}$ Hoe vernederend het urenlange wachten voor Wilhelm II in Eijsden waarschijnlijk was, toch mocht hij zich gelukkig prijzen

20 Zie het uitgebreide verslag van de toenmalige Duitse gezant in Nederland: Friedrich Rosen, Aus einem diplomatischen Wanderleben. Ende des Kaiserreichs - Weimarer Republik (Wiesbaden 1959) 216-220. 21 Pekelder, 'Leven in een luchtkasteel', XXXVIIXXXVII.

22 Jan Bank, 'Der Weg des Kaisers ins Exil', in: Hans Wilderotter en Klaus-D. Pohl ed., Der letzte Kaiser. Wilhelm II. im Exil (Gütersloh 1991) 105-112.

23 Ilsemann, Dagboekfragmenten, 26. vooraf niet in de handen van Duitse revolutionairen gevallen te zijn.

De vraag onder welke precieze omstandigheden Wilhelm II Nederland binnenkwam is meer dan een detailvraag omdat hierbij ook de algemene Nederlandse houding in de Eerste Wereldoorlog aan bod komt. Het uitleveringsvraagstuk dat vooral in 1919 en het voorjaar 1920, ook in Doorn, een rol speelde, draaide niet enkel om Wilhelm II. ${ }^{24}$ Het ging hier ook om de vraag of Nederland niet al tijdens de oorlog haar neutrale houding te Duitsgezind had geïnterpreteerd en er daardoor eventuele territoriale compensaties voor België aan de orde waren. ${ }^{25}$ Beide vragen, waarom en hoe precies Wilhelm II werd toegestaan naar Nederland te emigreren en hoe de Nederlandse regering omging met de eisen om Wilhelm II uit te leveren, bevestigen de tendens in recent onderzoek om de complexiteit van de Nederlandse neutrale houding in de Grote Oorlog te onderstrepen. ${ }^{26}$

Voor Duitsland ligt de belangstelling voor de Weimarrepubliek vooral in het feit dat de vlucht van Wilhelm II als 'schandelijke daad' de restauratie van de monarchie onmogelijk maakte. Om die reden is lang over de precieze omstandigheden van de vlucht gediscussieerd. Zelfs

24 Voor de desbetreffende nervositeit in Doorn zie bijv. Ilsemann, Dagboekfragmenten,12 januari, 7 maart, 17 april, 12 mei, 8 juni, 9 juni, 26 juni, 3 juli, 12 juli, 13 juli, 25 september, 18 oktober, 6 december 1919 en 29 januari, 10 maart, 28 april 1920.

25 Hubert P. van Tuyll van Serooskerken, Small countries in a big power world. The Belgian Dutch conflict at Versailles, 1919 (Leiden 2016); Nigel J. Ashton en Duco Hellema, 'Hanging the Kaiser: Anglo-Dutch relations and the fate of Wilhelm II, 1918-20', Diplomacy \& Statecraft 11.2 (2000) 53-78.

26 Wim Klinkert, Samuël Kruizinga en Paul Moeyes, ed., Nederland neutraal. De Eerste Wereldoorlog 19141918 (Amsterdam 2014). 
detailvragen gaven aanleiding tot de publicatie van pamfletten en allerhande verslagen van mensen die min of meer van nabij de gebeurtenissen in Spa hadden gevolgd. De belangrijkste, vooral in het conservatieve kamp besproken vraag was of Wilhelm II niet een zogenoemde 'Königstod' aan het front had kunnen of zelfs moeten zoeken - en daardoor een mogelijk symbolisch vertrekpunt voor de restauratie van de Hohenzollernmonarchie zou hebben gegeven. In ieder geval maakten de omstandigheden van de vlucht, ook omdat deze talrijke negatieve ideeën over Wilhelm II leken te bevestigen, een restauratie in feite onmogelijk. Omdat de vlucht duidelijk tot een verdere vervreemding van de conservatieven van de ex-keizer bijdroeg, speelden de codes 'Spa' en 'Doorn' indirect ook de nazi's in de kaart. ${ }^{27}$

Een van de weinige thema's die Wilhelm II nog sympathie opleverden, was het uitleveringsvraagstuk dat zelfs in linkse kringen in Duitsland als vernederend werd ervaren. Omdat het Nederlandse koningshuis en de Nederlandse regering er niet aan dachten om in te gaan op het verzoek van de geallieerden om uitlevering - en enkele van de geallieerde landen hiermee ook blijkbaar goed konden leven - bleef een eventueel proces tegen Wilhelm II een theoretische mogelijkheid. ${ }^{28}$ Het Verdrag van Versailles had een dergelijk proces echter concreet voorzien en voor het publiek in Groot-Brittannië, Frankrijk en vooral in België leek dit ook een evidentie te zijn. Vanuit het perspectief van de professionele historicus is

27 Voor de perceptie van de vlucht en de discussies daaromtrent: Kohlrausch, Monarch im Skandal, 325361.

28 Blijkbaar was er een poging van de Nederlandse regering om Wilhelm II in de winter van 1918/19 terug naar Duitsland te sturen. Rosen, Wanderleben, 249. de vraag of Wilhelm II veroordeeld zou zijn misschien minder interessant dan de contrafactische vraag wat een dergelijk proces zou hebben betekend. Zou een degelijke discussie over de gebeurtenissen in 1914 tot een grondiger uiteenzetting van de feiten in Duitsland hebben bijgedragen dan in de historische realiteit - en daardoor ook eventueel positieve gevolgen voor de Weimarrepubliek hebben gehad? ${ }^{29}$ Of zou Wilhelm II een soort martelaar geworden zijn, in de Duitse perceptie enkel slachtoffer van geallieerde Siegerjustiz, en dus misschien zelf van een proces hebben kunnen 'profiteren'?

In 2016 werden naar aanleiding van een langjarig project van de Stichting Studiecentrum Eerste Wereldoorlog de resultaten van een soort experiment schriftelijk voorgelegd. Met medewerking van enkele professionele rechtsgeleerden wordt in het al genoemde Het proces tegen Wilhelm II de rechtszaak tegen de ex-keizer vooralsnog aangespannen, weliswaar fictief. In de inleiding en ook grote delen van het boek nemen de auteurs een houding aan die men in de historische literatuur als revisionistisch zou beschouwen. Daaruit blijkt duidelijk hoe sterk nog altijd het lot van Wilhelm II en de herinnering aan de Eerste Wereldoorlog in Nederland samenhangen. De auteurs beweren dat ze als Nederlandse historici en rechtskundigen een quasineutrale positie innemen en dus bijzonder geschikt zijn om tot een rechtvaardig oordeel te komen. ${ }^{30}$ Honderd jaar na de oorlog lijkt dit een eigenaardige stelling, zoals ook blijkt uit het feit

29 Jürgen Mattäus, "The lessons of Leipzig. Punishing German war criminals after the First World War', in: Patricia Heberer ed., Atrocities on trial. Historical perspectives on the politics of prosecuting war crimes (Lincoln 2008) 3-23, aldaar 18-20.

30 Andriessen, Proces tegen Wilhelm II, 10. 
dat bijvoorbeeld de Brits-Australische historicus Christopher Clark duidelijk milder over de Duitse Kriegsschuld oordeelt dan vele Duitse historici. ${ }^{31}$

In het gedachte-experiment van een fictief proces komen zeker enkele interessante aspecten aan de oppervlakte. Zonder twijfel hebben de auteurs behoorlijke inspanningen geleverd om het internationale recht zoals het na de Eerste Wereldoorlog min of meer geaccepteerd was op de casus Wilhelm II toe te passen. Nochtans liggen precies hier, in de puur juridische benadering, ook de grenzen van een dergelijk experiment. Afgezien daarvan kan er over de beoordelingen lang gediscussieerd worden. De drie 'rechters' in Het proces veroordelen Wilhelm II enkel voor de door hem niet belette schending van de Belgische neutraliteit, niet voor de andere vier aanklachten zoals oorlogsmisdaden begaan in België. Uiteindelijk moeten de auteurs op enkele punten zelf toegeven dat de feiten eigenlijk te complex zijn om ze met redelijk beperkte juridische beginselen te vatten.

Het boek draagt dan ook weinig bij tot de historische beoordeling van Wilhelm II. Deze hangt altijd vooral af van twee criteria: ten eerste, hoe beslissend was Wilhelm II in de politieke structuur van het Duitse Keizerrijk en de Duitse oorlogsmachine en, ten tweede, welke doelen had Wilhelm II met zijn politieke beleid en wat waren zijn persoonlijke overtuigingen? In het bijzonder John Röhl heeft de politieke belangstelling van Wilhelm II benadrukt en vele keren op de rampzalige

31 Christopher Clark, The sleepwalkers. How Europe went to war (Londen 2012). Kritische recensies bijv. door Volker Ullrich in Die Zeit, 12 september 2013 en Hans-Ulrich Wehler in Frankfurter Allgemeine Zeitung, 7 mei 2014. politieke doeleinden van Wilhelm II gewezen. ${ }^{32}$ Ook Christopher Clark heeft de invloed van Wilhelm II gerelativeerd en ook de politieke stellingen van Wilhelm II als vaak problematisch maar ook weer niet zo ongewoon in het tijdperk van imperialisme beoordeeld. ${ }^{33}$

Het perspectief vanuit Doorn kan het eerste deel van deze controverse - dus de vraag welke rol Wilhelm II in het politieke stelsel van het keizerrijk speelde - uiteraard niet ophelderen. Nochtans laat het ballingschap een duidelijk zicht toe op het tweede deel van de problematiek, de politieke overtuigingen van Wilhelm II. De focus op de ex-keizer als privémens wiens blijkbaar ergste maatregel het decimeren van de bomen in het park van Doorn was, werpt de vraag op in hoeverre het de persoonlijkheid zelf was die tot de ramp van 1914 leidde. Was het niet eerder een ambt met een verantwoordelijkheid die in een dynamisch-industrieel tijdperk nooit in de handen van een individu had mogen terechtkomen? Ook Ilsemanns optekeningen geven geen antwoord op deze vraag. Wat daarin wel duidelijk naar voren komt, is dat Wilhelm II nauwelijks beschikte over de kenmerken van een 'ideale' heerser, zoals nuchter afwegen, mensenkennis of op basis van uitgebreide informatie tot een grondig oordeel komen. Het is niet verrassend dat dit in een situatie die enorme verantwoordelijkheden in één persoon concentreerde ook verregaande gevolgen moest hebben.

De lakmoesproef van de politieke overtuigingen van Wilhelm II was zijn houding tegenover het nationaalsocialisme. Met de opmars van de nazi's in Duitsland

32 Röhl, Aufbau en Röhl, Weg in den Abgrund.

33 Christopher Clark, Kaiser Wilhelm II. A life in power (Harlow 2000). 
eind jaren twintig steeg ook de belangstelling voor de keizerlijke balling weer. De nazi's hadden weinig animo voor de oudkeizer die ze als een voorbeeld van lafheid en gebrek aan echt leiderschap beschouwden. Wat de Hohenzollerns voor de nazi's interessant maakte, was dat zij een brug naar de oude conservatieve elites vormden. De Hohenzollerndynastie was daarmee nog altijd een belangrijke bron van legitimiteit en symbolische steun door de keizerlijke familie kon zo feitelijke politieke betekenis krijgen. In het bijzonder prins August-Wilhelm en minder uitgesproken ook de voormalige kroonprins, die zijn Nederlandse oord van ballingschap op het eiland Wieringen al in 1923 kon verlaten, zagen er overigens ook geen been in hun positieve houding tegenover Hitler openbaar te tonen. Beiden hoopten daardoor opnieuw een politieke rol te kunnen spelen. ${ }^{34}$

In Doorn, dit blijkt duidelijk uit Ilsemanns dagboeken, speelde het nazisme een belangrijke rol. Dit was vooral zo omdat de tweede vrouw van Wilhelm II, Hermine, geboren prinses Reuß ältere Linie, weduwe van Georg prins von SchoenaichCarolath, met wie Wilhelm in 1922 trouwde, als deuropener optrad en heel actief probeerde banden met Hitler en Hermann Göring te leggen om haar man een weg terug naar de troon te banen. ${ }^{35}$ Wilhelm II zelf was duidelijk terughoudender tegenover de nazi's en - een van

\footnotetext{
34 Kuipers, Kaiser, 89.

35 De herinneringen van Hermine werden in de vroege jaren dertig onder de titel 'Mijn Leven en hoe ik den Keizer trouwde' in het populaire tijdschrift Het Leven gepubliceerd en in 2008 in het Duits uitgegeven: Hermine Prinzessin von Preußen. Der Kaiser und ich. Mein Leben mit Kaiser Wilhelm II. im Exil. Herausgegeben aus dem Niederländischen übersetzt und kommentiert von Jens-Uwe Brinkmann (Göttingen 2008).
}

de zeldzame gevallen - ook duidelijk realistischer in zijn inschatting wat de mogelijke steun van Hitler voor een eventuele restauratie van de monarchie betrof. Uit Ilsemanns dagboeken blijkt minder duidelijk of deze terughoudendheid zijn oorsprong vond in een echte afkeur voor de nazi's of eerder voortkwam uit de teleurstelling over Hitlers gebrek aan steun voor het monarchisme. Anderzijds heeft Röhl terecht benadrukt dat de ingrediënten van het nationaalsocialisme bijna allemaal in statements van de geëxcelleerde keizer terug te vinden zijn. Dit geldt vooral voor enkele drastische antisemitische uitspraken. ${ }^{36}$

Voor de nazi's bleef Doorn een gevoelig thema. Het is opmerkelijk dat Hitler zelf voor de Duitse invasie van Nederland nauwkeurige maatregelen trof met betrekking tot de vraag hoe het Duitse leger met de ex-keizer en Doorn zou moeten omgaan. Ook na de bezetting van Nederland nam Hitler precieze voorzorgen om te voorkomen dat Duitse soldaten in contact met de oud-monarch zouden komen. ${ }^{37}$ Blijkbaar aarzelde de top van de naziregering of er niet toch nog substantiële oude loyaliteiten tegenover de monarch zouden bestaan en in ieder geval leek het raadzaam om geen publiciteit aan de keizer te geven.

Het vraagstuk hoe Wilhelm II en de

36 John C.G. Röhl, 'The unicorn in winter. Kaiser Wilhelm II in exile in the Netherlands, 1918-1941', in: Philip Mansel en Torsten Riotte ed., Monarchy and exile. The politics of legitimacy from Marie de Médicis to Wilhelm II. (Hampshire 2011) 337-351, aldaar 338. Zie ook: Gutsche, Exil, 78 .

37 Dit blijkt uit de bronnen van het Duitse leger: Microfilm in de US National Archives Maryland, bestand German records, T. 314, Film R 4444, pages FR 394-401 (originele akte in het Bundesarchiv-Militärarchiv, Freiburg). Met dank aan Jochen Böhler, Jena, voor de aanwijzing. 


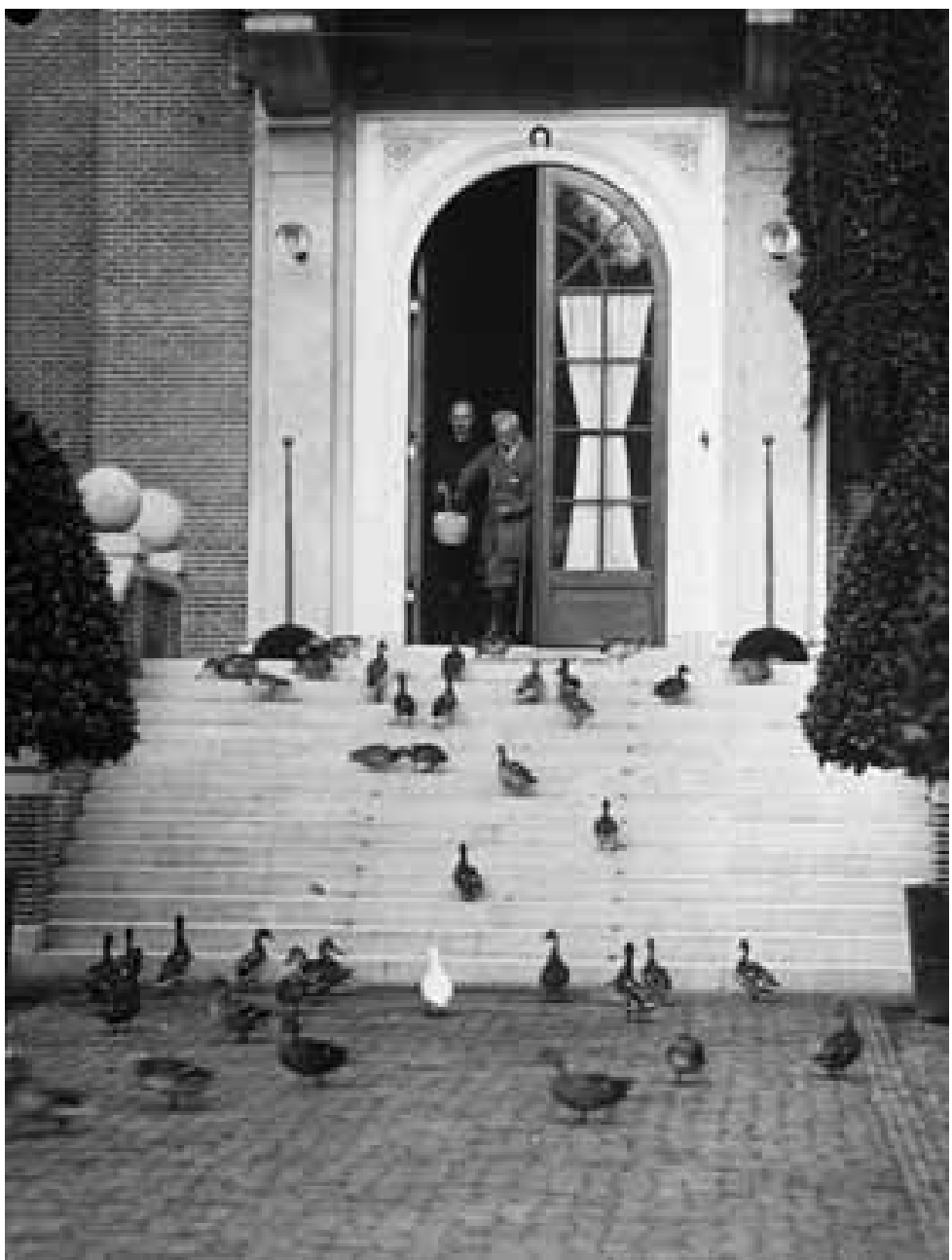

Wilhelm II voedert eenden voor het kasteel Doorn in het jaar 1931. Het privéleven van de ex-keizer als 'Grand Seigneur', ver verwijderd van de economische crisis in de Weimarrepubliek, zorgde voor kwaad bloed in Duitsland en vormde een groot obstakel voor het Duitse monarchisme.

Bundesarchiv, Bild 102-11797 / foto: Georg Pahl

Hohenzollerns tegenover de nazi's stonden is ook vandaag nog van enige, weliswaar vooral juridisch-financiële, relevantie. De Nederlandse regering baseerde haar besluit Huis Doorn in 1945 te sekwestreren op de stelling dat de Hohenzollerns, vooral de kroonprins, de vijand hadden gesteund. Maar ook in een nog altijd aanslepende strijd van de huidige chef van het huis Hohenzollern om het toenmalige eigendom van de familie terug te verwerven - overigens ook met betrekking tot Huis Doorn - komt de relatie van de exkroonprins met de nazi's een beslissende rol toe. ${ }^{38}$

38 Stephan Malinowski, 'Der braune Kronprinz', Die Zeit, 27 augustus 2015 . 


\section{Huis Doorn - Wilhelm II en Nederland}

Afgezien van de in een algemener historisch kader belangrijke vragen wat betreft vlucht, uitlevering en houding van Wilhelm II tegenover het nationaalsocialisme brengt het dagboek van Ilsemann ook heel wat informatie over het miniatuurhof in Doorn en de bijbehorende - en soms redelijk absurde - routines naar voren. ${ }^{39} \mathrm{De}$ keizer en zijn omgeving leverden aanzienlijke inspanningen om betekenis te geven aan een dagdagelijks leven dat op zich niets meer te maken had met dat van de man die zich enkele jaren daarvoor als de machtigste leider ter wereld beschouwde. Kuipers weet bijvoorbeeld te berichten dat Huis Doorn onder Wilhelm II een officieel meteorologisch weerstation werd met allerlei meteorologische toestellen en met Wilhelm II als opperste meteoroloog die zijn weerkundige berichten aan het KNMI nog altijd met I.R. (Imperator Rex) tekende. ${ }^{40}$

De bijna enige doorbreking van de voor Ilsemann amper te verdragen saaiheid van de routines in een claustrofobische sfeer waren bezoeken aan Doorn. Naast talrijke monarchisten vond ook een aantal prominente tijdgenoten zijn weg naar Doorn. Misschien de meest opmerkelijke onder deze gasten was de in die tijd heel invloedrijke antropoloog Leo Frobenius. Een recente wetenschappelijke uitgave van de lang verdwenen correspondentie tussen Frobenius en Wilhelm II heeft de omvang van Frobenius' activiteiten in

39 Hans Wilderotter, 'Haus Doorn. Die verkleinerte Kopie eines Hofstaats', in: Hans Wilderotter en KlausD. Pohl ed., Der letzte Kaiser. Wilhelm II. im Exil (Gütersloh 1991) 113-122, aldaar 113.

40 Kuipers, Kaiser, 97.
Doorn toegelicht. ${ }^{41}$ In het kader van een speciaal opgerichte Doorner Arbeitsgemeinschaft kwamen met Frobenius enkele archeologen samen die gebruikmaakten van de al voor 1914 bestaande fascinatie van Wilhelm II voor de archeologie. Voor de wetenschappers boden deze bijeenkomsten de kans de ex-keizer te ontmoeten en vooral voor Frobenius de gelegenheid om financiële steun voor onderzoek en expedities te verwerven. De keizer, in ruil, profiteerde van de voor hem nu zeldzame mogelijkheid om aandacht te krijgen en enkele van zijn opvattingen aan etnologische theorieën te spiegelen. ${ }^{42}$

Zo modern als de vrij individualistische en zelf ingenomen gelukzoeker overkomt, is ook de 'beeldpolitiek' in Doorn die al in 2002 door Saskia Asser en Liesbeth Ruitenberg met de bundel De keizer in beeld in kaart werd gebracht. Enkele voorbeelden uit de indrukwekkende Doornse fotocollectie zijn in de nieuwe uitgave van de dagboeken van Ilsemann en het boek Der Kaiser terug te vinden. Deze afbeeldingen tonen aan hoe de Hohenzollerns het moderne medium fotografie omhelsden en privédoelen redelijk gemakkelijk met de - nu in exil noodzakelijk beperkte - politieke propaganda voor de keizer vermengden. $^{43}$

De fotocollectie maakt samen met de inhoud van de toen beruchte 59 treinwa-

41 Christoph Johannes Franzen, Karl-Heinz Kohl en Marie-Luise Recker ed., Der Kaiser und sein Forscher. Der Briefwechsel zwischen Wilhelm II. und Leo Frobenius (1924-1938) (Stuttgart 2012).

42 De omgeving van de keizer had het duidelijk moeilijk om de ex-keizer in zijn wetenschappelijke interesses te volgen. Zie de symbolieke verbranding van een 'Gorgo', beschreven in: Ilsemann, Dagboekfragmenten, 73-74.

43 Saskia Asser en Liesbeth Ruitenberg ed., De keizer in beeld. Wilhelm II en de fotografie als PR-instrument (Zaltbommel 2002). 
gons die de bijna failliete Republiek van Weimar de keizer achterna stuurde, deel uit van het Doornse patrimonium. Na het einde van de Tweede Wereldoorlog werd het domein, dat de Nederlandse staat tot dan toe als extraterritoriaal beschouwde, onderdeel van het Nederlandse grondgebied. Over de noodzaak Doorn te sekwestreren bestond na de Tweede Wereldoorlog, gezien de politieke houding van de Hohenzollerns en vooral het karakter van het Duitse bezettingsregime, nauwelijks twijfel. Maar daarom was het nog niet vanzelfsprekend dat Nederland ook Huis Doorn zou overnemen. Als vijandelijk vermogen had men het bezit - zoals in andere gevallen - gewoon kunnen liquideren. Dit werd blijkbaar vooral door leden van de lokale elite verhinderd. Doorn wordt sindsdien door een stichting en met substantiële steun van de Nederlandse overheid in stand gehouden. ${ }^{44}$

Terwijl Huis Doorn vele decennia lang een plek van vooral lokale betekenis bleef en een lieu de mémoire voor de sowieso niet talrijke en snel verminderende Duitse monarchisten, kwam er na het jaar 2000 een verandering in de na de oorlog gemaakte arrangementen. De Raad van Cultuur stelde de overheidsfinanciering voor Doorn in vraag gezien de voor Nederland toch vrij beperkte betekenis van de plek (en de dalende bezoekersaantallen). In een soort compromis werd uiteindelijk besloten Huis Doorn als museum te laten blijven bestaan maar dan wel met een verminderde overheidsbijdrage en met de hulp van vrijwilligers. Het Huis Doorn van vandaag is duidelijk een plaats waar

44 Ceciel Huitema, Nederlandse trots achter een Duitse façade. Motieven voor het behoud van Huis Doorn, 1945-1952 (Masterscriptie Geschiedenis Rijksuniversiteit Groningen 2007) 4. de oude emoties omtrent een van de meest controversiële historische figuren nog maar een kleine rol spelen. Het museum organiseert bijvoorbeeld workshops 'vorstelijk tafeldekken' en probeert zo een nieuw publiek te bereiken. Bovendien werd besloten Doorn met de op andere plekken in Nederland nauwelijks bestaande herinnering aan de Eerste Wereldoorlog te verbinden. Door Huis Doorn met de herinnering aan de Eerste Wereldoorlog in Nederland te koppelen werd getracht om op de golf van herinnering omtrent de jaren 1914-1918 en de toch al toenemende interesse voor de Eerste Wereldoorlog in Nederland in te spelen. ${ }^{45}$ Door de verbouwing van de toenmalige garage van Wilhelm II en de plaatsing van een glazen paviljoen werd ruimte gemaakt voor een tentoonstelling over de Nederlandse neutraliteit in de Eerste Wereldoorlog en wisselexposities. ${ }^{46}$

Terwijl het op zich positief is de geschiedenis nuchter te benaderen en het zeker beter is Doorn als plek van herinnering in stand de houden in plaats van het gewoon uit de Nederlandse en Duitse geschiedenis te laten verdwijnen, kan men om goede redenen vraagtekens plaatsen bij de recente trend van musealisering van de keizer. In 2011 werd in het Rijksmuseum van Oudheden in Leiden een tentoonstelling over de 'gedeelde fascinatie van Elisabeth [van Oostenrijk] en Wil-

45 Voor de specifiek Nederlandse herinnering aan de Grote Oorlog zie: Kees Ribbens, 'Commemorating a "foreign" war in a neutral country. The political insignificance of World War 1 memory in the Netherlands', BMGN - Low Countries Historical Review, 131.3 (2016) 87-98. Voor een voorbeeld van een populaire benadering van de thematiek zie de uitgave 'Nederland en de Eerste Wereldoorlog', ThemaTijdschrift 3.1. (2014). 46 Zie de webpagina van Huis Doorn; http:// www.huisdoorn.nl/nl/. 


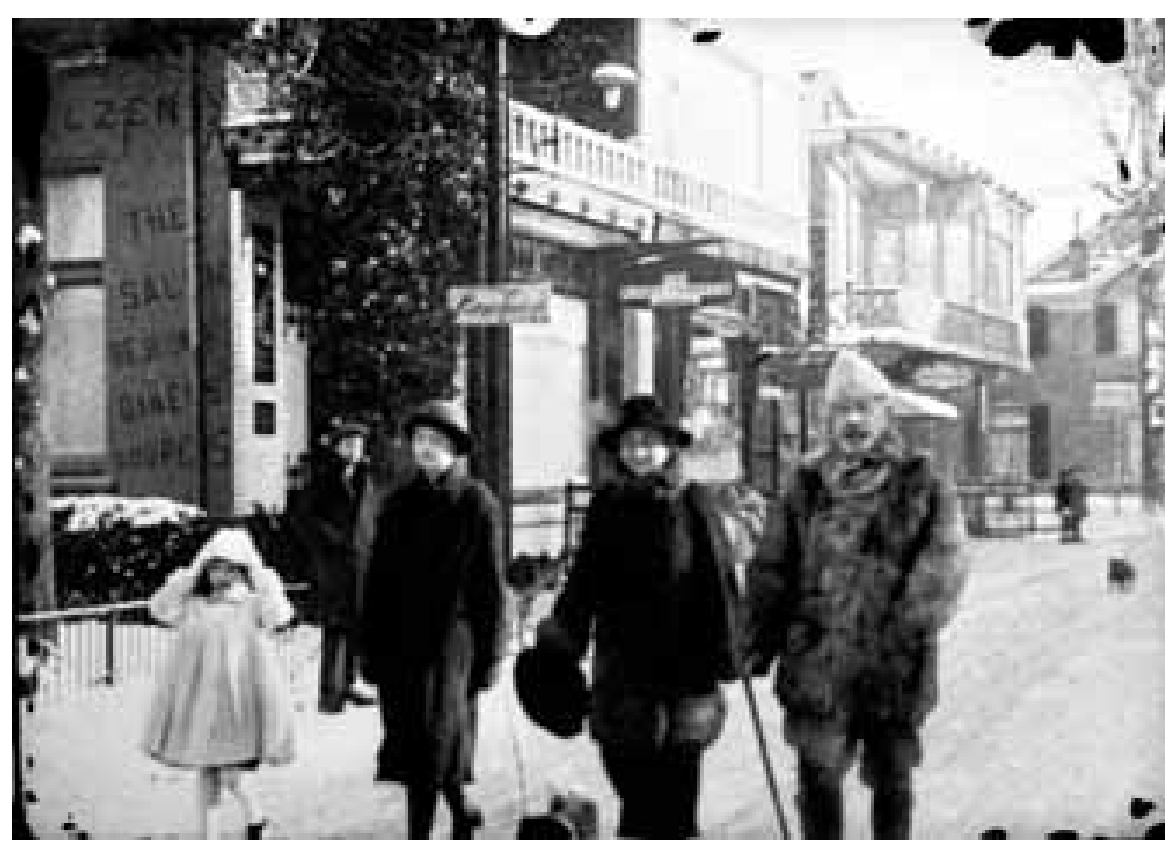

In Doorn was Wilhelm II een soort beroemdheid die het kleine dorpje internationale aandacht bracht. Hoewel Wilhelm II allesbehalve populair was in Nederland, schikten de inwoners van Doorn zich, ook om economische redenen, met de gast uit een ander tijdperk. De foto van een Nederlandse amateurfotograaf toont Wilhelm II met zijn tweede vrouw Hermine Prinzessin Reuß in Doorn in 1931. Bundesarchiv, Bild 102-1280o / foto: o.Ang.

helm II voor de oudheid', specifiek voor het Griekse eiland Corfu, georganiseerd. ${ }^{47}$ Met de aandacht op 'Sisi' en Wilhelm II op Corfu of op allerhande persoonlijke spullen van de keizer in de al vernoemde tentoonstelling 'Der Kaiser!' in Het Loo, die in 2015/16 doorging, is op zich niets mis. Maar bij gebrek aan bijkomende sterkere politiek-kritische verhalen dreigt deze musealisering wel de geschiedenis zonder haar politieke kern te presenteren.

47 Zie het tentoonstellingsboekje Marlite Halbertsma, Ruurd Halbertsma en Liesbeth Ruitenberg ed., Sisi \& Wilhelm. Keizers op Corfu. Het verhaal van de gedeelde fascinatie van Elisabeth en Wilhelm II voor de oudheid (Leiden 2011).

\section{Conclusie}

Het kan niet de bedoeling zijn de karikatuur van Wilhelm II als 'Beast of Berlin' gewoon verder te zetten - een karikatuur die ontstond tijdens de Eerste Wereldoorlog en ook te danken was aan de tekeningen en spotprenten van de Nederlander Louis Raemaekers. ${ }^{48}$ Veeleer is te hopen dat de nuancering en vooral verbreding van perspectief die de meer recente literatuur over Wilhelm II kenmerkt ook in de herinneringscultuur tot uitdrukking zal komen. Zelfs de laatste 23 jaar van Wilhelm II, dus het tijdperk na zijn abdicatie,

48 Ariane de Ranitz en Louis Raemaekers, 'Met pen en potlood als wapen.' Politiek tekenaar van wereldfaam in de Eerste Wereldoorlog (Roermond 2014); zie ook de talrijke voorbeelden in: Paul van Damme, Vriend over vijand. De Grote Oorlog in spotprenten (Tielt 2013). 
bestonden uit meer dan eenden voederen en bomen hakken. Mettertijd zou dus de vraag opnieuw moeten worden gesteld van wie 'Huis Doorn' eigenlijk is: een $\mathrm{Ne}$ derlands herenhuis, privébezit van de familie von Preußen of zelfs iets waarvoor de Duitse staat of Duitse culturele instituties moeten opkomen? Het antwoord op deze vraag kan geen louter financieelpraktisch antwoord zijn gezien de symbolische en historische achtergrond die in dit artikel werd uiteengezet.

De 'spullen' van de oude keizer zijn voor de Pruisische en Duitse geschiedenis echter wel van belang. Duitsland worstelt sowieso al met een plaats voor de herinnering aan de laatste keizer. Tot nu toe, zou men toegespitst kunnen zeggen, heeft men die problematiek vooral proberen op te lossen door vermijding van aandacht. Een bijkomend, zelden bedacht probleem is dat er in Duitsland zelf geen centrale plek bestaat voor een kritische uiteenzetting van de Pruisisch-Duitse monarchie, de Hohenzollerns en Wilhelm II in het bijzonder. Het Hohenzollern Museum in het Monbijou-palais is al lang verdwenen, de Stiftung Preußische Schlösser und Gärten in Berlijn en Potsdam is vooral gericht op erfgoedgebouwen. ${ }^{49}$ Het zal zeker interessant zijn om te zien of met de heropbouw van het Hohenzollern Palais in Berlijn, anders dan initieel gepland, ook inhoudelijk naar de oude beheerders

49 Jürgen Luh, 'Eine Erbschaft der Monarchie: Das Hohenzollern-Museum', in: Thomas Biskup en Martin Kohlrausch ed., Das Erbe der Monarchie. Nachwirkungen einer deutschen Institution (Frankfurt a.M. 2008) 200-216.

50 Zie Friedrich Dieckmann, Vom Schloss der Könige zum Forum der Republik. Zum Problem der architektonischen Wiederaufführung (Berlijn 2015); Rainer Haubrich, Das neue Berliner Schloss: Von der Hohenzollernresidenz zum Humboldtforum (Berlijn 2011). van het kasteel en hun rol in de Duitse en Europese geschiedenis zal worden verwezen. ${ }^{50}$ Dit onderwerp met de bouw van een zogenoemd 'Humboldt-Forum' helemaal aan de kant te laten staan, uit angst zich met een moeilijk en belast onderwerp bezig te houden, zou zeker de minst geschikte oplossing zijn.

En het zou vooral vreemd zijn om 100 jaar nadat het Duitse Rijk Nederland met een politieke Altlast heeft opgezadeld vanuit de Duitse kant niets terug te doen. Het is maar een kanttekening maar anderzijds ook kenmerkend voor de eigenaardige wegen van herinneringscultuur en de niet altijd evidente verbindingen daarvan op de achtergrond: sinds enkele jaren loopt in verband met de wederopbouw van het oude Hohenzollern-paleis in Berlijn een kleine controverse rond de terugkeer van de standbeelden van vijf Oranjevorsten op wellicht de meest centrale plek van de Duitse hoofdstad. De voorstanders van een origineelgetrouwe wederopbouw van het paleis doen hun best om de standbeelden van onder meer prins Maurits en prins Willem II als 'Symbol für die enge Freundschaft zwischen Deutschland und den Niederlanden in einem vereinten Europa' en voorvechters van religieuze tolerantie voor te stellen. ${ }^{51}$ Wilhelm II had de standbeelden in 1907 voor zijn paleis laten opstellen om

51 Zie de blog: http://berliner-schloss.de/blog/diestandbilder-der-oranierfuersten-auf-der-balustradeder-terrassenanlage-der-lustgartenseite-des-berlinerschlosses/ (geraadpleegd april 2017). Voor de historische realiteit van de relatie Oranje-Hohenzollern zie het door Paul Rem geschreven hoofdstuk 'Wilhelm II, een Duitse Prins van Oranje' in: Kuipers, Kaiser, 106111 . 
ein geschichtliches Zeugnis für die Verbundenheit der Häuser Hohenzollern und Oranien abzulegen und pietätvoll zu kennzeichnen, dass die ganze Geschichte, alle Freuden und Leiden und alle Erfolge der beiden Dynastien einst in engster persönlicher Verknüpfung sich vollzogen haben, die auch allen kommenden Geschlechtern gegenwärtig bleiben soll. ${ }^{52}$

Wetend wat er elf jaar later zou gebeuren, klinken deze bedoelingen onbedoeld komisch. Met zicht op de dichtbije herdenking naar aanleiding van 100 jaar einde van de Eerste Wereldoorlog, de vlucht van Wilhelm II naar Nederland, van het Verdrag van Versailles en van het uitleveringsvraagstuk is te hopen dat deze herinneringsdagen aanleiding zullen geven tot studies met een bredere opzet die hun oog ook richten op Nederlands-Duitse betrekkingen, de publieke rol van de monarchie maar ook op het vraagstuk 'herdenking' op zich. ${ }^{53}$
52 Albert Geyer, Geschichte des Schlosses zu Berlin. Vom Königsschloss zum Schloss des Kaisers (1698-1918) (Berlijn 1992) 130.

53 Voor een stand van zaken in een groeiend onderzoeksveld: Krijn Thijs en Rüdiger Haude ed., Grenzfälle. Transfer und Konflikt zwischen Deutschland, Belgien und den Niederlanden im 20. Jahrhundert (Heidelberg 2013).

\section{Over de auteur}

Dr. Martin Kohlrausch is hoofddocent Europese Politieke Geschiedenis aan de onderzoekseenheid Geschiedenis van de KU Leuven en hoofd van de Onderzoeksgroep 'Moderniteit en Samenleving'. Zijn onderzoeksinteresses gaan uit naar de geschiedenis van massamedia en politiek en van de geschiedenis van experten in de twintigste eeuw.

E-mail: martin.kohlrausch@kuleuven.be 